\title{
STRENGTHENING OF BUILDING
}

STRUCTURES OF HISTORICAL MASONRY

BUILDINGS IN SYRIA WITH CARBON FIBER

REINFORCED POLYMER (CFRP) RODS

\section{AND STAINLESS STEEL HELICAL RODS}

\section{Z.A. ALDREBI}

Emperor Alexander I St. Petersburg State Transport University, Moskovsky Ave., 9, Saint Petersburg, 190031, Russian Federation

The article presents the most innovative methods of strengthening and (or) seismic strengthening of masonry for use in historical buildings that are of architectural value, for example, in old mosques in Syria, which are architectural monuments. These methods are designed to protect such buildings, many of which are of architectural and cultural value and are on the UNESCO World Heritage List, from cracks of various sizes and directions and from the negative effects of earthquakes that can occur at any time. Carbon fiber reinforced polymer rods (CFRP) rods and stainless steel helical rods are considered. Two mosques in Syria are briefly described as examples of historical masonry buildings, which are architectural monuments and objects of cultural heritage. In the end conclusions are drawn.

Keywords: architectural monuments of Syria, building structures, earthquake, seismic strengthening, seismic resistance, crack, strengthening, carbon fiber reinforced polymer (CFRP) rods, stainless steel helical rods, NSM FRP technique

For citation: Aldrebi Z.A. Strengthening of building structures of historical masonry buildings in Syria with carbon fiber reinforced polymer (CFRP) rods and stainless steel helical rods. Bulletin of Science and Research Center of Construction. 2021. Vol. 31. No. 4. P. 120-133. doi: https://doi.org/10.37538/2224-9494-2021-4(31)-120-133

\section{Funding}

No funding support was obtained for the research.

\section{Conflict of interest}

The author declares no conflict of interest.

\section{УСИЛЕНИЕ СТРОИТЕЛЬНЫХ КОНСТРУКЦИЙ ИСТОРИЧЕСКИХ КАМЕННЫХ ЗДАНИЙ СИРИИ СТЕРЖНЯМИ ИЗ УГЛЕПОЛИМЕРА И СПИРАЛЬНЫМИ СТЕРЖНЯМИ ИЗ НЕРЖАВЕЮЩЕЙ СТАЛИ}

\author{
3.А. АЛЬДРЕБИ \\ ФГБОУ ВО «Петербургский государственный университет путей сообщения Императора Александра I», \\ Московский пр., д. 9, Санкт-Петербург, 190031, Российская Федерация
}

В статье приведены наиболее инновационные методы усиления и (или) сейсмоусиления каменной кладки для использования в исторических зданиях, которые представляют архитектурную ценность, 
например, в старых мечетях в Сирии, которые являются памятниками архитектуры. Эти методы призваны защитить такие здания, многие из которых имеют архитектурную и культурную ценность и входят в список Всемирного наследия ЮНЕСКО, от трещин различных размеров и направлений и от негативных воздействий землетрясений, которые могут произойти в любой момент. Рассмотрены стержни из углеполимера и спиральные стержни из нержавеющей стали. Кратко описаны в качестве примера исторических каменных зданий две мечети в Сирии, которые являются памятниками архитектуры и объектами культурного наследия. В конце сделаны выводы.

Ключевые слова: памятники архитектуры Сирии, строительные конструкции, землетрясение, сейсмоусиление, сейсмостойкость, трещина, усиление, стержни из углеполимера, спиральные стержни из нержавеющей стали, техника усиления установкой у поверхности стержней из углеполимера

Для цитирования: Альдреби З.А. Усиление строительных конструкций исторических каменных зданий Сирии стержнями из углеполимера и спиральными стержнями из нержавеющей стали // Вестник НИЦ «Строительство». 2021. Т. 31. № 4. С. 120-133. doi: https://doi.org/10.37538/2224-9494-2021-4(31)-120-133

\section{Финансирование}

Исследование не имело спонсорской поддержки.

\section{Конфликт интересов}

Автор заявляет об отсутствии конфликта интересов.

\section{Introduction}

Existing historical buildings, built of masonry, some of which are architectural monuments, are located in different countries for example Russia, Italy, Greece, Spain, and Syria [1-4]. Architectural monuments in Syria such as mosques, churches and temples are an important part of the architectural and cultural heritage of humankind. They are susceptible to various negative environmental influences, including earthquakes that have occurred in this country for centuries [5-7].

For strengthening and (or) seismic strengthening of buildings and structures, there are traditional methods, that is, without changing the dynamic scheme and non-traditional methods that involve changing the dynamic scheme. This article discusses only traditional methods, but with one caveat that they are innovative [6].

It is worth noting that similar buildings and structures are common all over the world, therefore, the approaches to strengthening given in this article are suitable for use everywhere in them. These historical buildings and structures were usually built of unreinforced masonry, so they are vulnerable to earthquakes and other natural and unnatural disasters [5-7].

Buildings with unreinforced stone walls are structures characterized by inadequate earthquake [8-9] behavior due to their low ductility and low energy dissipation capacity. Consequently, these structures are very vulnerable to this kind of natural phenomena and can face sudden failures that can even lead to their complete destruction.

This was observed during previous earthquakes, such as the earthquakes in Tashkent, in the USSR with a magnitude of 5.2, in 1966; in Los Angeles, USA, in 1994 with a magnitude of 6.7; in Mexico, in 2003 with a magnitude of 7.6; in Chile in 2010 with a magnitude of 8.8 and others. 


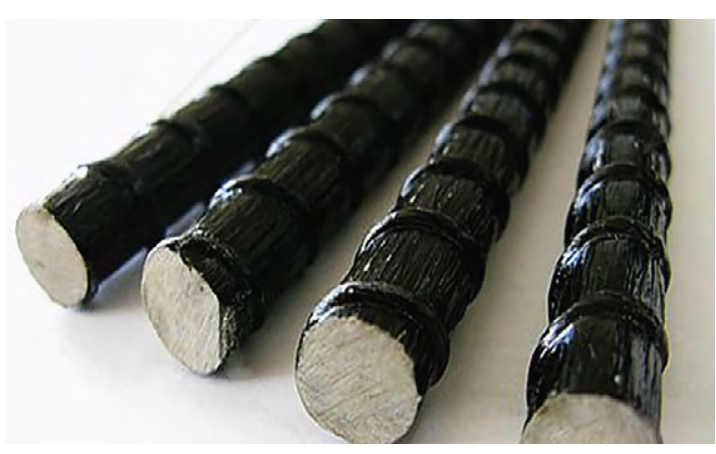

Fig. 1. Carbon fiber-reinforced polymer (CFRP) rods Рис. 1. Стержни из углеполимера

\section{Methods}

One of the innovative traditional methods of strengthening and (or) seismic strengthening of buildings and structures is carbon fiber reinforced plastics (CFRP), which are polymer composite reinforced with carbon fiber materials, and are known as an alternative to the traditional steel rods for reinforcement of masonry and other building structures. They are lightweight and resistant to corrosion, as well as high tensile strength and high modulus of elasticity. These polymers are available in a variety of forms, including sheets, fabrics, and reinforcing bars (Fig. 1).

Numerous studies have shown that FRP systems are effective in increasing the shear and flexural strength of stone walls subjected to in-plane loads. The structural performance of a FRP-reinforced stone wall depends on the configuration of the reinforcement.

In recent years, external reinforcement of stone walls with composite strips and rods has become more common in many countries.

However, in different countries, there was a distrust of composite materials, which led to not considering such materials as an alternative to traditional reinforcement, and there is still little research on this issue. Therefore, this research in the article aims to contribute to the study of the behavior of these innovative materials so that they can be considered as external reinforcement for stone walls.

Another type of reinforcement is stainless steel screw (helical) rods (Fig. 2, $a$ ) and wires (Fig. 2,b), which can not only be used as a reinforcement for masonry joints similar to CFRP rods, but also use them as anchors for arched lintels, fastening corner walls to each other.

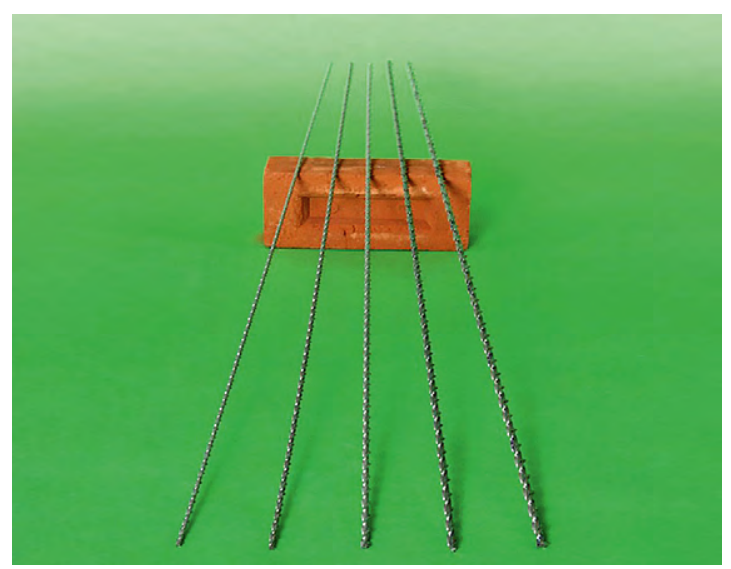

a

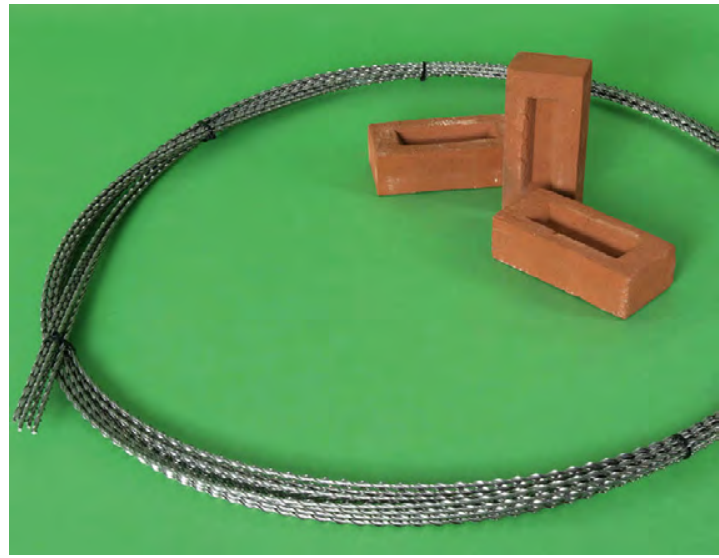

b

Fig. 2. Stainless steel helical rods and wire: $a$ - stainless steel helical rods; $b$ - stainless steel helical wire

Рис. 2. Спиральные стержни и проволоки из нержавеющей стали: а - спиральные стержни из нержавеющей стали; $b$ - спиральная проволока из нержавеющей стали 
Severe damage or total loss of cultural heritage sites as a result of strong earthquakes has occurred throughout the history of mankind. These unexpected and inevitable events demonstrated that masonry buildings and structures are one of the most vulnerable types of structures that can be severely damaged or collapsed. Their protection is a matter of great concern to the scientific community. This concern mainly arises from the observed damage after each major earthquake, as well as the need and interest in preserving them. Therefore, the seismic resistance of buildings and structures is an important element of the preservation of such objects [5-10].

The technical characteristics of stainless steel helical rods and carbon fiber-reinforced polymer (CFRP) rods are shown in Tables 1 and 2.

Table 1

Technical characteristics of stainless steel helical rods

Таблица 1

Технические характеристики спиральных стержней из нержавеющей стали

\begin{tabular}{|c|c|c|c|}
\hline \multicolumn{2}{|c|}{ Technical characteristics } & 8 & 10 \\
\hline Nominal diameter, mm & 6 & 2 & 2 \\
\hline Number of turns, pcs & 2 & 30 & 50 \\
\hline Step of turns mm & 25 & 0,079 & 0,011 \\
\hline Weight, kg / I.m. & 0,067 & 10 & 13 \\
\hline Cross-sectional area, mm ${ }^{2}$ & 8 & 3,57 & 4,07 \\
\hline Core width, mm & 3,19 & 11,22 & 12,79 \\
\hline Section perimeter, mm & 10,02 & $8,8 / 7,5$ & $10,7 / 8,3$ \\
\hline Tensile strength/ yield point, kN & $7,2 / 6,0$ & 148 & 146 \\
\hline
\end{tabular}

Table 2

Technical characteristics of carbon fiber-reinforced polymer (CFRP) rods

Таблица 2

Технические характеристики стержней из углеполимера

\begin{tabular}{|c|c|c|c|c|c|c|}
\hline \multicolumn{7}{|c|}{ Technical characteristics } \\
\hline Diameter, $\mathrm{mm}$ & 3 & 4 & 6 & 8 & 10 & 12 \\
\hline Cross-sectional area, $\mathrm{mm}^{2}$ & 7 & 12 & 28 & 50 & 73 & 103 \\
\hline Density $\left(\mathrm{g} / \mathrm{cm}^{3}\right)$ & 2,2 & 2,2 & 2,2 & 2,2 & 2,2 & 2,1 \\
\hline Weight $(\mathrm{g} / \mathrm{m})$ & 18 & 32 & 51 & 98 & 150 & 210 \\
\hline Ultimate tensile strength, MPa & 1900 & 1500 & 1280 & 1080 & 980 & 870 \\
\hline Elastic modulus, GPa & $>40$ & $>40$ & $>40$ & $>40$ & $>40$ & $>40$ \\
\hline
\end{tabular}




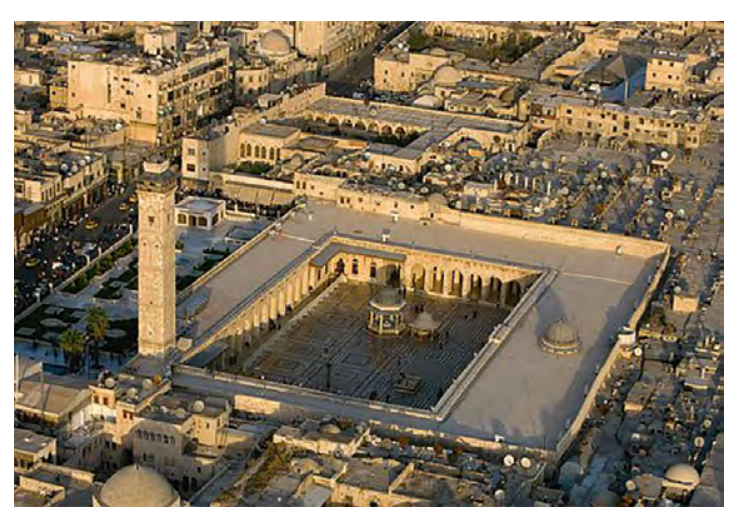

Fig. 3. Great Mosque of Aleppo, Syria

Рис. 3. Великая мечеть в г. Алеппо, Сирия

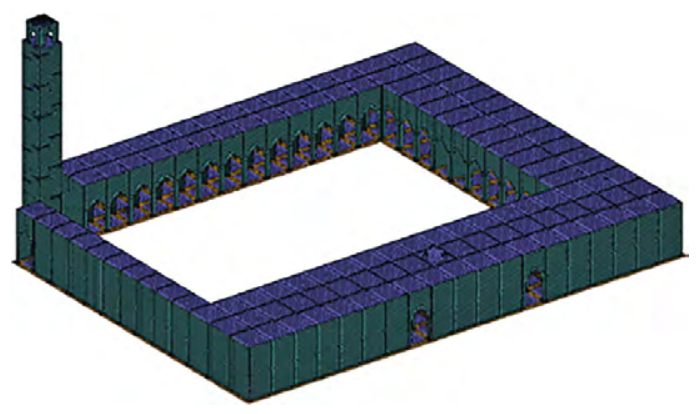

Fig. 4. Design model of the Great Mosque of Aleppo (condition after restoration)

Рис. 4. Расчетная модель Великой мечети в г. Алеппо, Сирия (состояние после реставрации)

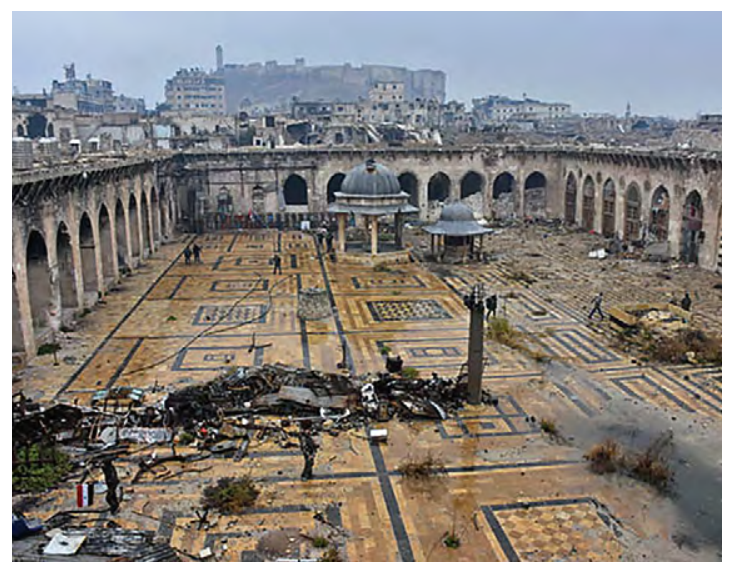

Fig. 5. Damage to the building of the Great mosque in Aleppo, Syria as a result of hostilities

Рис. 5. Повреждения в здании Великой мечети в г. Алеппо, Сирия, в результате военных действий

\section{Historical masonry buildings}

Striking examples of historical buildings, built of masonry and at the same time being masterpieces, and monuments of architecture are the Great Mosque in Aleppo and the Al-Adiliya Mosque in Aleppo in Syria.

The Great Mosque of Aleppo City is one of the largest and oldest Muslim buildings of religious significance in Syria (Fig. 3, 4). The building began to be built in 715 . The plan of the Great Mosque is rectangular with a rectangular courtyard; its dimensions are $105 \times 78 \mathrm{~m}$. On the northwest side, there is a rectangular minaret with dimensions at the base of $4.85 \times 4.85 \mathrm{~m}$. Galleries, columns and arches surround the courtyard. Past earthquakes and hostilities damaged the building structures of the Great Mosque of Aleppo and led to the formation of various cracks and other damage (Fig. 5). The minaret collapsed in 2013. The building was included in the UNESCO World Heritage List in $1986[1-7,10]$. The author proposes the restoration (Fig.4) of this building using, among other things, the rods described above.

The Al-Adiliya Mosque is located in the old part of the city of Aleppo in Syria (Fig. 6), the

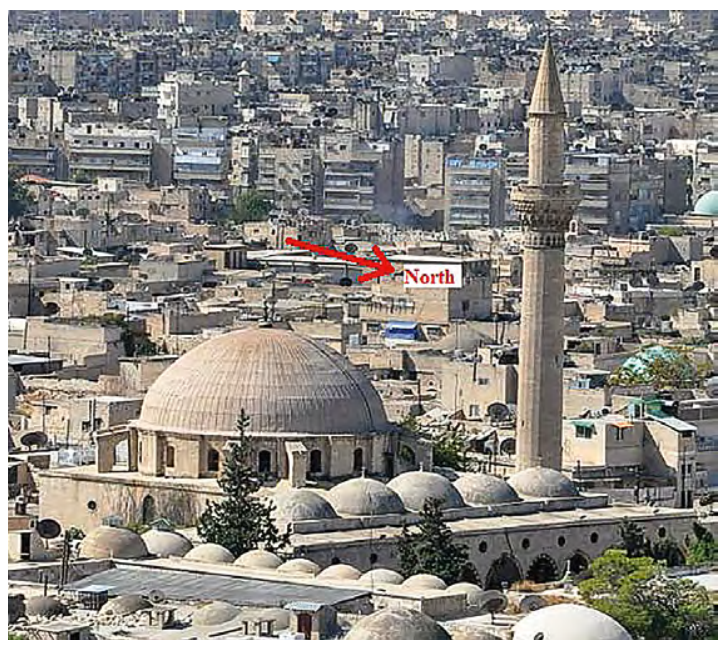

Fig. 6. Al-Adiliyah Mosque in Aleppo, Syria

Рис. 6. Мечеть Аль-Адилия в г. Алеппо, Сирия 


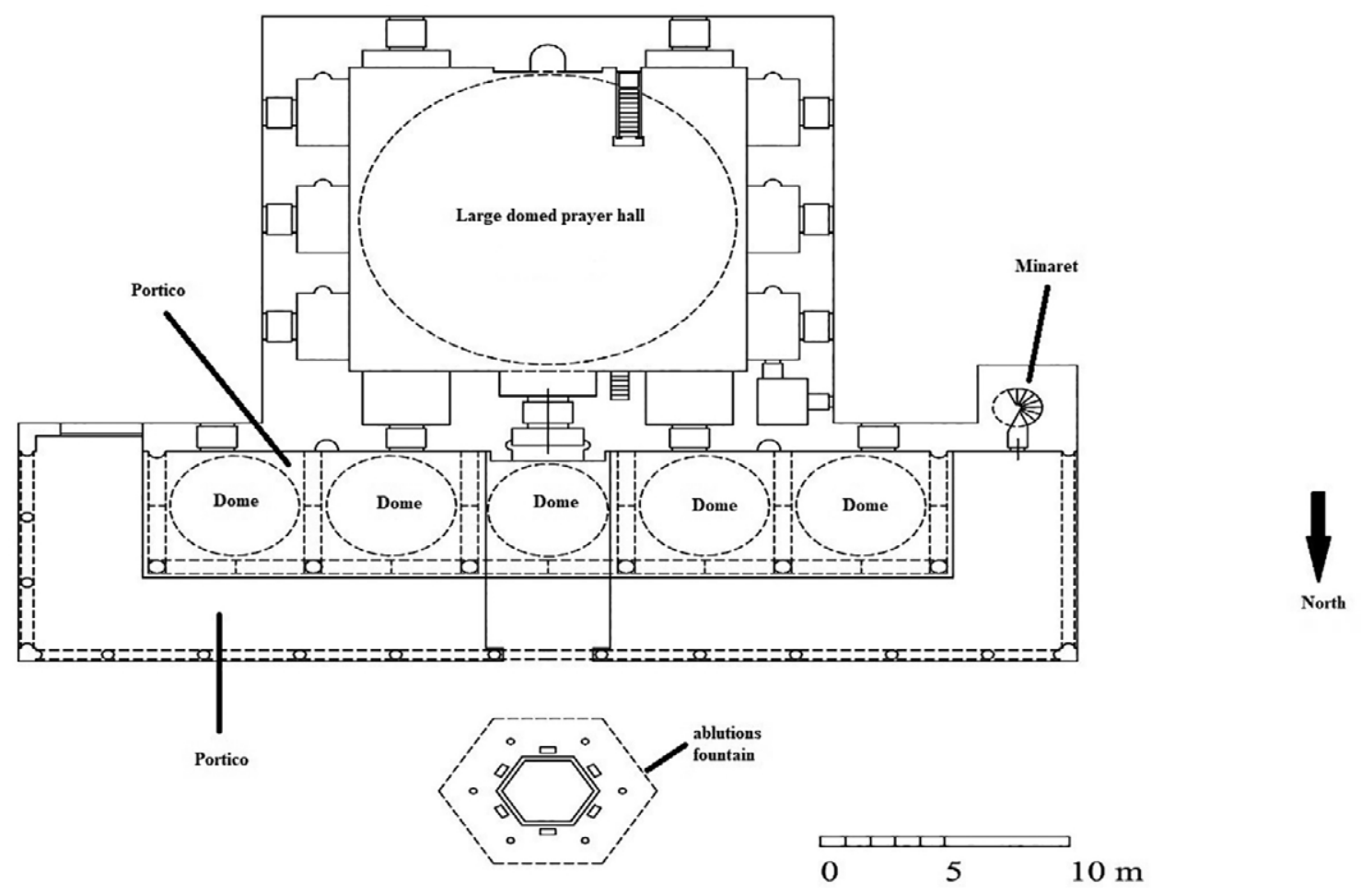

Fig. 7. The plan of Al-Adiliyah Mosque in Aleppo, Syria Рис. 7. План мечети Аль-Адилия в г. Алеппо, Сирия

beginning of its construction in 1557; the building is built of masonry. Its plan is square; each side is about $15.6 \mathrm{~m}$ long (Fig. 7). The building has galleries, columns and arches. The mosque has a rectangular courtyard with two east and west entrances. In the courtyard, there is a domed fountain for ablution of believers. In the west of the mosque there is a cylindrical minaret with a height of about $40 \mathrm{~m}$. The mosque was built in the Ottoman style of architecture. It has one large spherical dome and five small ones. The building of the mosque was damaged (Fig. 8) by past earthquakes and hostilities $[1-7,10]$.

Fig. 8. Damage to the building of the Al-Adiliya mosque in Aleppo, Syria as a result of hostilities

Рис. 8. Повреждения в здании мечети Аль-Адилия в г. Алеппо в результате военных действий, Сирия

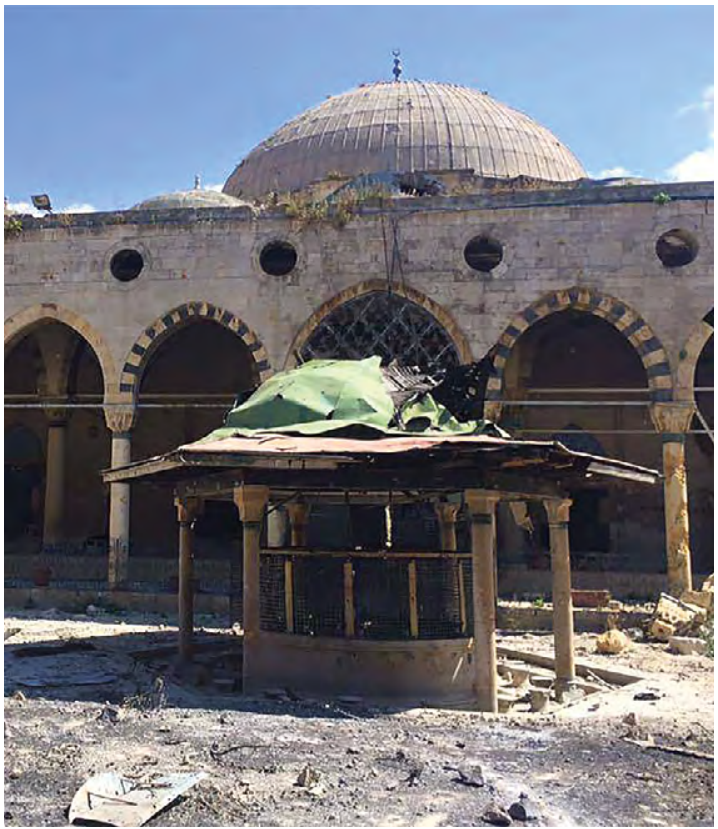




\section{Masonry reinforcement technology}

The technology consists in using screw (helical) rods made of stainless steel. This method is a modern and effective way to strengthening the masonry against cracks. It has recently been used in Europe to strengthen masonry when cracks appear [11, 12].

The tensile strength of the material of such rods is twice that of conventional reinforcement.

Stainless steel helical rods have a small diameter, therefore, when using them, small grooves and holes are required, which in turn almost does not affect the strength of the structure being repaired and does not require a large consumption of mortar for the joints.

Instead of stainless steel helical rods (bars) to strengthen masonry, including damaged ones, you can use carbon fiber reinforced polymer (CFRP) rods, which are composite material that is more resistant to corrosion than stainless steel. This reinforcement method is called Near Surface Mounted (NSM) FRP Technique or NSM Technique [13, 14].

\section{Technology "Stitching Cracked Walls"}

The installation of the rods is carried out as follows:

- using a circular saw, cut the groove in the most horizontal mortar seam of the masonry, (it is also allowed to cut the groove outside the horizontal mortar joint of the masonry, that is, in the masonry material itself);

- the depth of the groove is about $60 \mathrm{~mm}$ (or half of a stone brick), its minimum width is $10 \mathrm{~mm}$;

- the groove should be cleaned with water and dried with compressed air, followed by the injection of a binder solution into the groove with a pistol;

- then the rod is mounted in the groove;

- a binder solution is pumped over the rod to fix it and the finishing work is carried out (Fig. 9). Such technology called "Stitching Cracked Walls" in Europe.

\section{Strengthening masonry in the presence of cracks}

Follow the same steps listed earlier.

The rod is installed so that it spans $500 \mathrm{~mm}$ on each side cracks (Fig. 10).

Injection of cracks with mortar is carried out, then finishing works and painting are carried out if necessary.

\section{Strengthening and anchoring lintels in the presence of cracks}

It is carried out with the help of stainless steel screw rods (helical bars) which are screwed into the pre-prepared holes in the body of regular and arched lintels (Figs. 11, 12).

\section{Strengthening and anchoring of stone facades in the presence of cracks}

Stainless steel helical rods are screwed into pre-prepared holes in the body of the facade masonry (Fig. 13). 

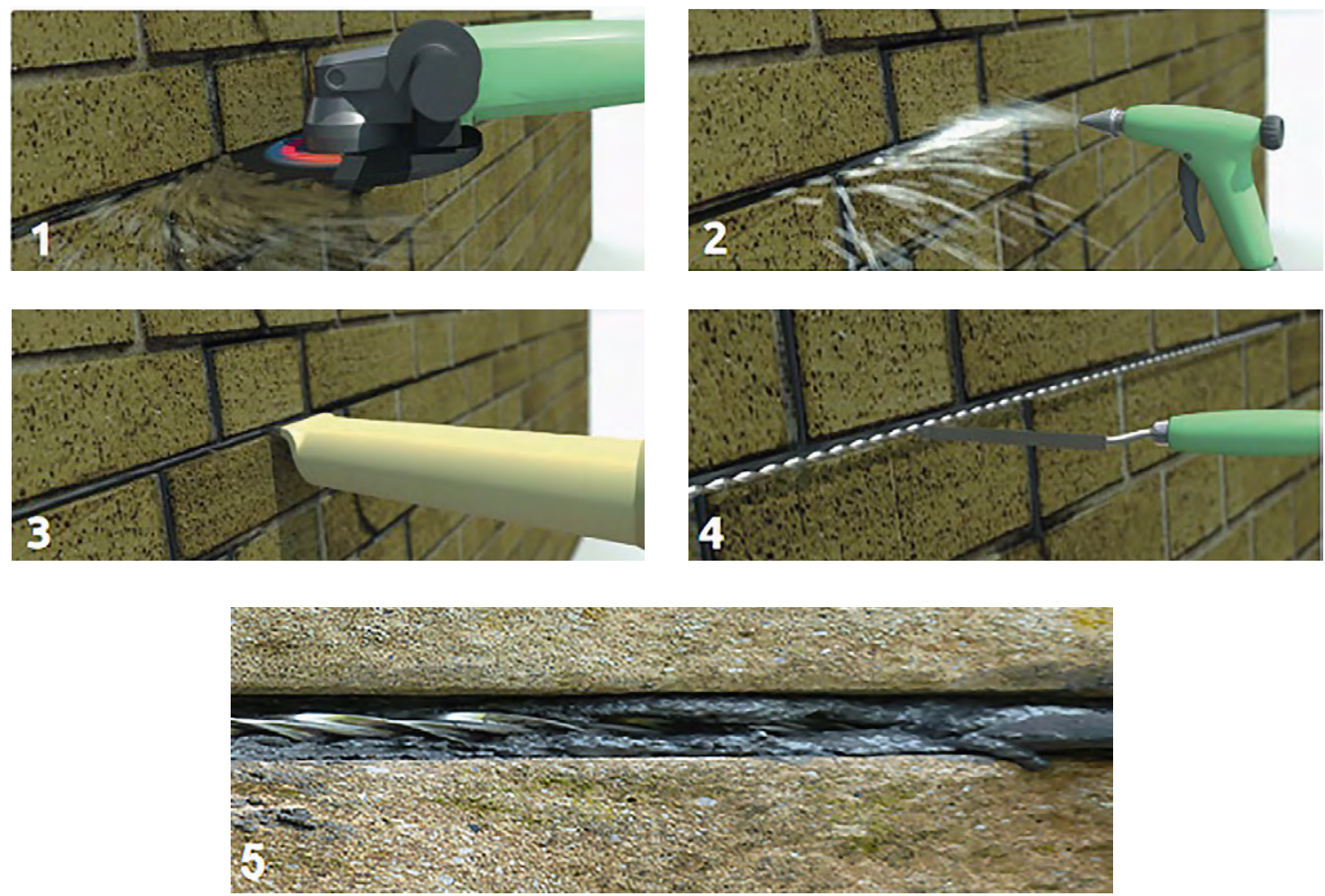

Fig. 9. Cracked wall repair technology called "Stitching Cracked Walls" in Europe

1 - cut a groove in the seam between the stones; 2 - cleaning the groove with water and compressed air; 3 - injection of a special binder solution to a depth of about $1 \mathrm{~cm}$ deep into the groove; 4 - installation of the rod deep into the groove and sealing the seam with a spatula with the same mortar; 5 - sealing the crack by injecting mortar

Рис. 9. Технология ремонта стен с трещинами, называемая в Европе «зашивка потрескавшихся стен»: 1 - прорезание канавки в шве между камнями; 2 - очистка канавки водой и сжатым воздухом; 3 - впрыскивание специального вяжущего раствора на глубину около 1 см вглубь канавки; 4 - установка стержня вглубь канавки и заделка шва шпателем тем же раствором; 5 - заделка трещины с помощью инъецирования раствора

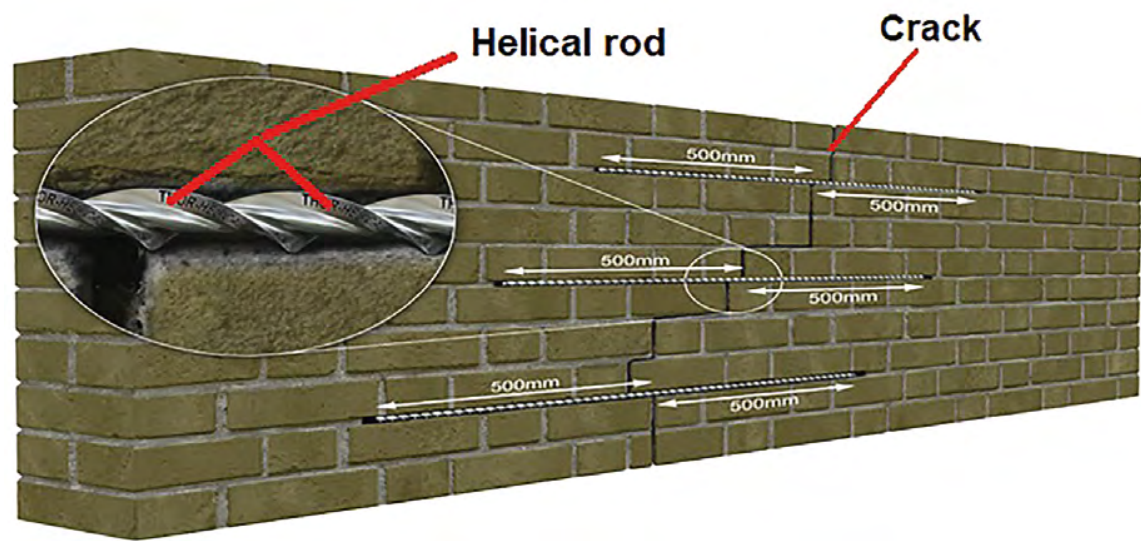

Fig. 10. Strengthening masonry in the presence of cracks

Рис. 10. Усиление кладки при наличии трещин 

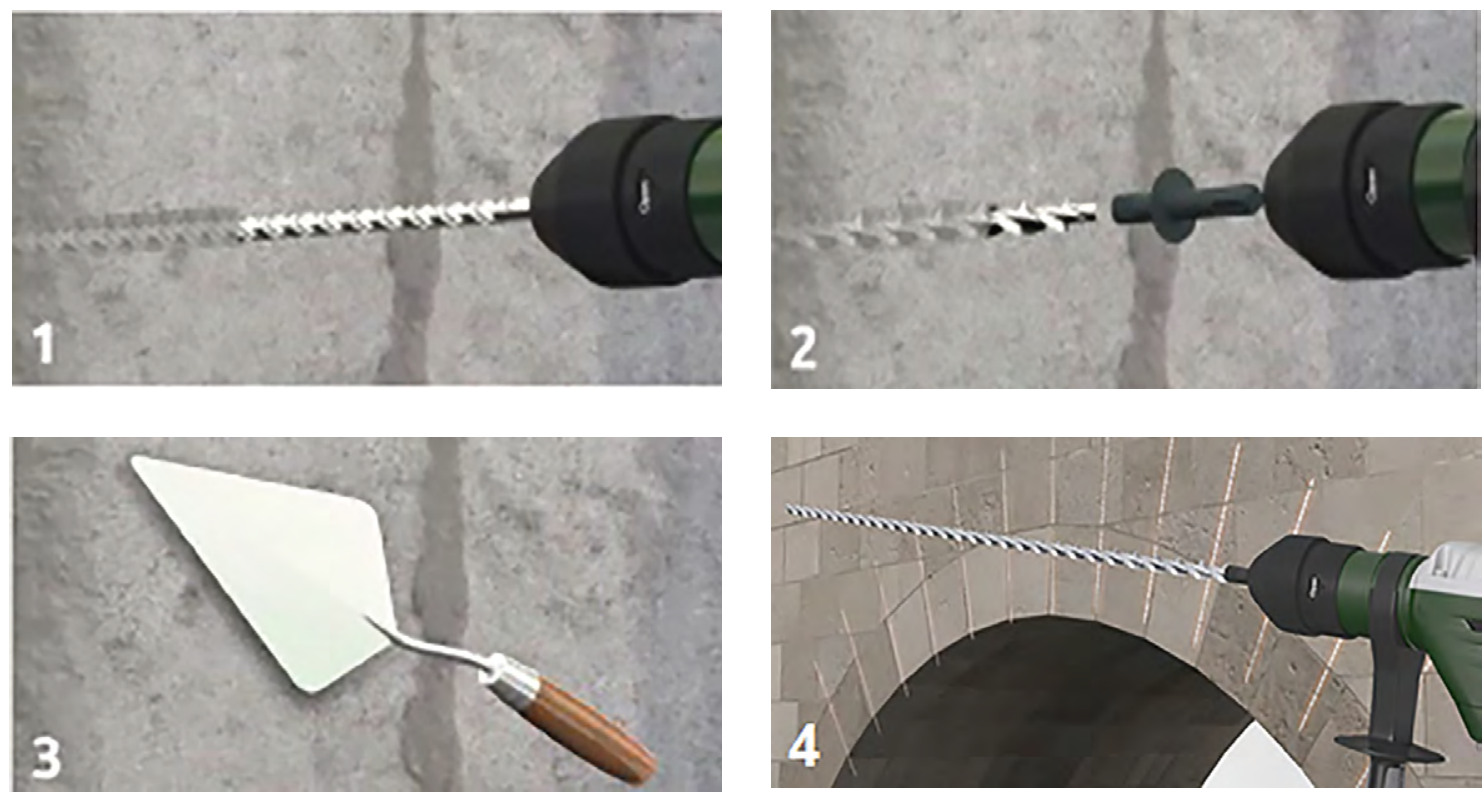

Fig. 11. Anchorage of arch lintels: 1 - drill masonry; 2 - installation of stainless steel helical rod; 3 - sealing the drilling site; 4 - the final view of the arched lintel with the rods installed

Рис. 11. Анкеровка арочных перемычек: 1 - просверливание кладки; 2 - установка спирального стержня из нержавеющей стали; 3 - заделка места сверления; 4 - окончательный вид арочной перемычки с установленными стержнями
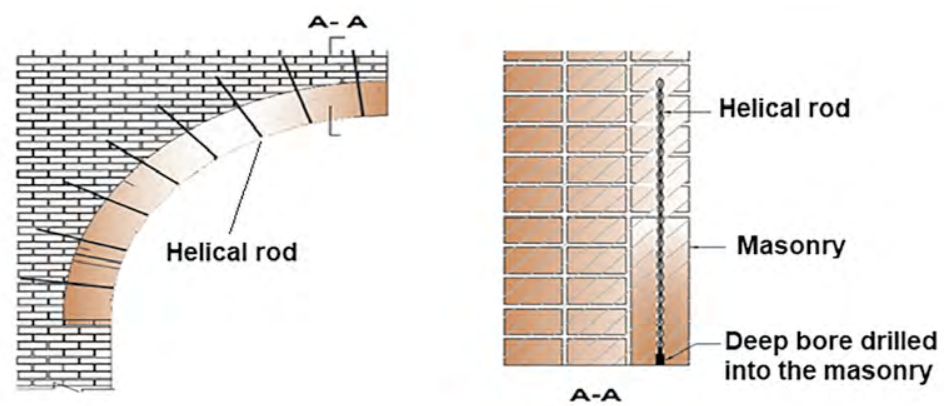

Fig. 12. Sectional view of anchorage of arched lintels Рис. 12. Анкеровка арочных перемычек в разрезе

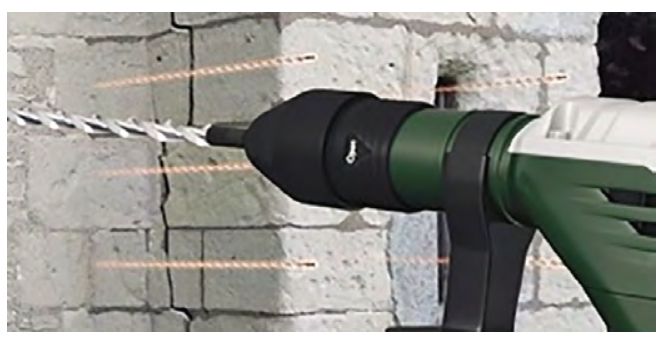

Fig. 13. Anchorage of the facade masonry

Рис. 13. Анкеровка каменных фасадов 


\section{Strengthening and anchoring corner walls in the presence of cracks}

To strengthen the corners of the walls (stitching cracks at corner), you can use a stainless steel wire bent in the shape of right angle (Fig. 14).

It is carried out with the help of stainless steel screw rods that are screwed into pre-prepared holes in the body of the wall masonry (Fig. 15).

Such helical rods are produced in various European countries. For example, in Russia they are produced by company GYDROZO. They are available in diameters of 5, 6, 7, 8 and $9 \mathrm{~mm}$, in standard lengths of 1 and $2 \mathrm{~m}$.

The carbon fiber reinforced polymer (CFRP) rods are produced, for example, by the Swiss company Sika.

\section{Calculation algorithm}

The helical rods and carbon fiber reinforced polymer (CFRP) rods are used to absorb tensile forces that exceed acceptable values, which affects the formation and development of cracks in masonry [15-19].

To calculate the reinforcement of masonry with these kinds of rods, a number of tasks should be performed:

- determine the bearing capacity of the masonry of the building structures of the reinforced building;

- highlight weak zones and load values that exceed the design stresses;

- determine the direction of action of the loads;

- calculate the number of rods that are required to accommodate the excess loads [15].

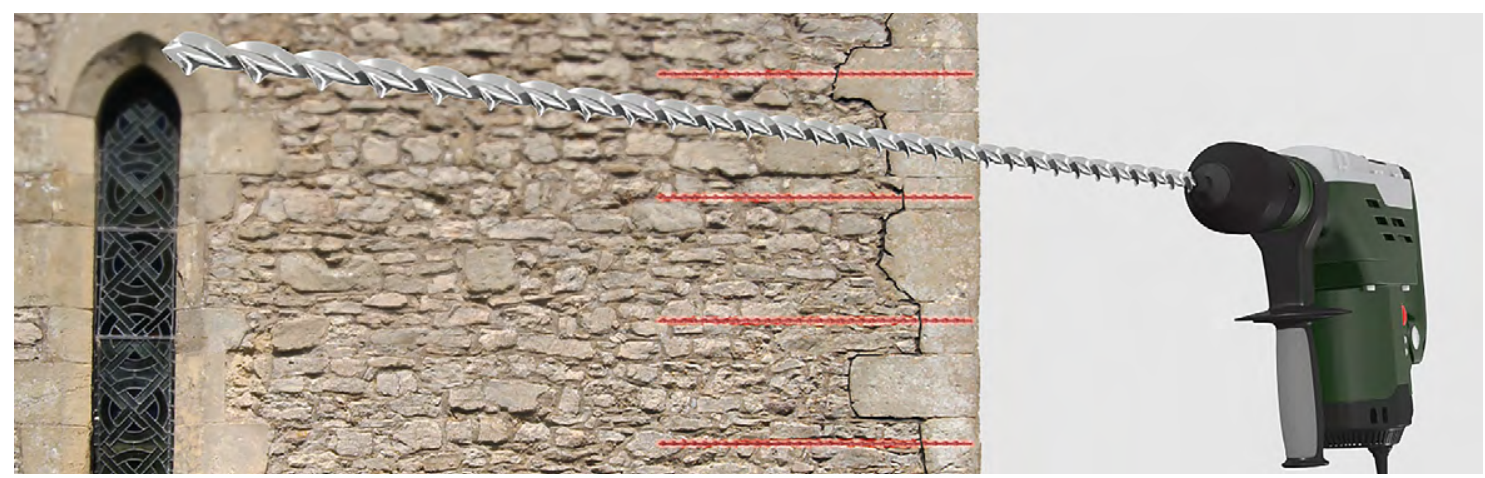

Fig. 15. Anchorage of corner walls

Рис. 15. Анкеровка угловых стен 
The method of calculating masonry building structures, reinforced with carbon fiber reinforced polymer (CFRP) rods, or stainless steel helical rods under central compression is based on calculation methods from SP.15.13330.2012 «Stone and reinforced stone structures» [16] , that is, to calculate the elements of stone building structures under central compression [20], reinforced with external rods, made of CFRP or helical rods made of stainless steel, according to the formula:

where

$$
N \leq m_{g} \cdot m_{k} \cdot \varphi \cdot R_{r f} \cdot A,
$$

$N$ - calculated longitudinal force;

$m_{g}-$ the coefficient, taking into account the effect of a long load;

$m_{k}$ - the coefficient of masonry working conditions ( $m_{k}=1$ for masonry without damage, $m_{k}=0,7$ with damage);

$\varphi$ - buckling coefficient, determined by SP.15.13330.2012 «Stone and reinforced stone structures»; $A$ - sectional area of element;

$R_{r f}$ - calculated compression resistance of the masonry, reinforced with external reinforcement of CFRP rods or stainless steel helical rods and determined by the formula:

$$
R_{r f}=R+\rho \cdot \mu \cdot \frac{R_{f}}{100} \leq 2 \cdot R
$$

$\rho$ - the coefficient depending on the percentage of the masonry void: $\rho=2-$ with a stone void up to $20 \%$ inclusive, $\rho=1.5$ with a stone void from 20 to $30 \%$ inclusive, $\rho=1$ with a void of more than $30 \%$;

$\mu$ - coefficient of surface reinforcement of walls (columns);

$R$ - calculated compression resistance of the masonry, determined by SP.15.13330.2012 «Stone and reinforced stone structures».

If the engineer knows the design tensile resistance of the masonry, he will be able to determine the zones of building structures where the stress exceeds the permissible values. The lack of bearing capacity of the masonry in each finite element must be compensated for by reinforcement with stainless steel helical rods or carbon fiber reinforced polymer (CFRP) rods.

To determine the required number of rods, in each finite element where excess stresses are present, you can use the formula:

$$
R_{\text {bars }}=\frac{2 \cdot \mu \cdot R_{f}}{100}
$$

where

$R_{\text {bars }}$ - the design resistance of the reinforcing material (helical bars or CFRP rods);

$R_{f}$ - design tensile strength of the bar material.

According to the formulas from SP 15.13330.2012 "Stone and reinforced stone structures" the coefficient of surface reinforcement $\mu$ is determined:

$$
\mu=\frac{V_{\text {bars }}}{V_{\text {masonry }}} \cdot 100
$$


where

$\mu$ - coefficient of surface reinforcement of walls (columns);

$V_{\text {bars }}$ - sectional area of reinforcement;

$V_{\text {masonry }}$ - cross-sectional area of masonry.

\section{Advantages of rods}

The above-described helical rods and carbon fiber reinforced polymer (CFRP) rods have many advantages:

- not subject to corrosion;

- small in diameter and light in weight;

- work in the elastic stage of deformation;

- do not reduce the aesthetic qualities of the masonry;

- good chemical resistance;

- possess high mechanical characteristics;

- reduce tensile stresses in masonry;

- work in tension and shear;

- they can be used for any type of masonry.

\section{Conclusions}

Masonry is widely appreciated all over the world due to various important factors such as durability, availability, bioclimatic characteristics, low cost compared to other materials such as steel and reinforced concrete, but along with these qualities it also has disadvantages, such as the inability to mechanize the masonry process, low labor productivity, large relative mass of structures. Historical buildings and structures built of masonry are an important part of the monuments of world architecture because they are common all over the world. Many of these monuments are on the UNESCO World Heritage List. Reinforcement, including seismic reinforcement of such buildings and structures, can be performed using various methods: both traditional and special. The importance of maintaining their authenticity is of great significance if they are of architectural value. The above method of reinforcing buildings and structures built of masonry with carbon fiber reinforced polymer rods (CFRP) and stainless steel helical rods is ideal from the point of view of maintaining authenticity. The author believes that this method of strengthening (seismic strengthening) of building structures of buildings that are architectural monuments, such as the Great Mosque of Aleppo in Syria, can be used for its restoration, especially since it has not been previously used in this Arab country. Such an innovative method deserves the attention of scientists and engineers around the world for the strengthening and (or) seismic strengthening of many similar buildings and structures built of masonry, taking into account the advantages over other traditional methods. 


\section{References}

1. Всеобщая история архитектуры: в 12 т. / гл. ред. Н. В. Баранов; Государственный комитет гражданского строительства и архитектуры Госстроя СССР, Научно-исследовательский институт теории и перспективных проблем советской архитектуры. - Москва: Стройиздат, 1970. - Т. 1: Архитектура Древнего мира / под ред. О.Х. Халпахчьяна. - 512 с.

2. Всеобщая история архитектуры: в 12 т. / гл. ред. Н. В. Баранов; Государственный комитет гражданского строительства и архитектуры Госстроя СССР, Научно-исследовательский институт теории и перспективных проблем советской архитектуры. - Москва: Стройиздат, 1973. - Т. 2: Архитектура Древнего мира (Греция и Рим) / отв. ред. В. Ф. Маркузон. - 712 с.

3. Всеобщая история архитектуры: в 12 т. / гл. ред. А. В. Власов; ред. Н. В. Баранов [и др.]; Государственный комитет гражданского строительства и архитектуры Госстроя СССР, Научно-исследовательский институт теории и перспективных проблем советской архитектуры. - Москва: Стройиздат, 1969. - Т. 8: Архитектура Стран Средиземноморья, Африки и Азии (VI-XIX вв.) / отв. ред. Ю. С. Яралов; ред. Б.В. Веймарн [и др.]. - 688 с. 4. Шуази О. История архитектуры: в 2-х т. / Огюст Шуази; пер. с фр. Е. Г. Денисовой; под общ. ред. Ю.К. Милова, А.А. Сидорова. - Москва: Всесоюзное изд-во Архитектурной академии, 1937. - Т. 2. - 692 с. 5. Альдреби 3.А. Сейсмическая опасность территории Сирии / З.А. Альдреби // Сейсмостойкое строительство. Безопасность сооружений. - 2019. - № 6. - С. 43-48.

6. Альдреби 3.А. Мониторинг и паспортизация наиболее известных архитектурных памятников Сирии / 3.А. Альдреби // Известия Петербургского университета путей сообщения. - 2018. - Т. 15, № 2. - С. 302-310.

7. Белаш Т.А. Анализ повреждений памятников архитектуры Сирии, полученных в результате землетрясений и военных действий / Т.А. Белаш, 3.А. Альдреби // Сейсмостойкое строительство. Безопасность сооружений. - 2016. - № 5. - С. 58-63.

8. СП 14.13330.2018. Строительство в сейсмических районах: свод правил: Актуализированная редакция СНиП II-7-81. - Москва: Стандартинформ, 2018 - 116 с.

9. ГОСТ Р 57546-2017. Землетрясения. Шкала сейсмической интенсивности: национальный стандарт Российской Федерации. - Москва: Стандартинформ, 2017. - 32 с.

10. Alafandi R. Umayyad Mosque in Aleppo yesterday, today and tomorrow / R. Alafandi, A.A. Rahim // International Journal of Arts \& Sciences. - 2014. - Vol. 7, no. 5. - P. 319-347.

11. Бедов А.И. Проектирование, реставрация и укрепление каменных и армокаменных конструкций: учеб. пособ. / А.И. Бедов, А.И. Габитов. - Москва: Издательство Ассоциации строительных вузов, 2008. - 568 с.

12. Гроздов В.Т. Дефекты конструкций каменных зданий и методы их устранения / В.Т. Гроздов. - СПб: ВИСИ, 1994. - 145 с.

13. Guide for the Design and Construction of Externally Bonded FRP Systems for Strengthening Concrete Structures: Reported by ACI Committee 440 / American Concrete Institute (ACI). - Farmington Hills, MI, USA, 2008. - 80 p.

14. Bischof P. Retrofitting Masonry Walls with Carbon Mesh / P. Bischof, R. Suter // Polymers. - 2014. - Vol. 6, no. 2. - P. 280-299. https://doi.org/10.3390/polym6020280

15. СП 20.13330.2016. Нагрузки и воздействия: свод правил: Актуализированная редакция СНиП 2.01.0785*. - Москва: ЦНИИСК им. В.А. Кучеренко, 2016. - 107 с.

16. СП 15.13330.2012. Каменные и армокаменные конструкции: свод правил: Актуализированная редакция СНиП II-22-81* (с Изменениями № 1,2). - Москва: ЦНИИСК им. В. А. Кучеренко, 2012. - 99 с.

17. Albert L.M. Strengthening of Unreinforced Masonry Walls Using FRP / L.M. Albert, A.E. Elwi, J.J. Cheng // Journal of Composites for Construction. - 2001. - Vol. 5, no. 2. - P. 76-84.

18. Tumialan J.G. Strengthening of Masonry Structures with FRP Composites: Doctoral Dissertation / J.G. Tumialan. - Rolla, Missouri: University of Missouri-Rolla, 2001. - 186 p.

19. Applications of FRP Materials for Repair of Masonry Structures / A. La Tegola, Al. La Tegola, L. De Lorenzis [et al.] // Proceedings of the Technology Transfer Seminar Advanced FRP Materials for Civil Structures, Bologna, Italy. October 19 2000. - Bologna, Italy, 2000. - P. 133-142.

20. Костенко А.Н. Прочность и деформативность центрально и внецентренно сжатых кирпичных и железобетонных колонн, усиленных угле- и стекловолокном: автореф. дис. ... канд. тех. наук: 05.23.01/ А.Н. Костенко. - Москва, 2010. - 26 с. 


\section{Information about author / Информация об авторе}

Ziad Ahmad ALDREBI, Researcher, Lecturer-researcher, Civil engineer, Postgraduate, Emperor Alexander I St. Petersburg State Transport University, Saint Petersburg

e-mail: ziald67@gmail.com

tel.: +7 (911) 836-36-27

Зиад Ахмад АЛЬДРЕБИ, исследователь, преподаватель-исследователь, инженер-строитель, аспирант ФГБОУ ВО «Петербургский государственный университет путей сообщения Императора Александра І», Санкт-Петербург

e-mail: ziald67@gmail.com

тел.: +7 (911) 836-36-27 